\title{
The Conflicting Uses of Prison Visitation in Mandate Palestine
}

\author{
Orna Alyagon Darr(i) and Rachela Er`el
}

\begin{abstract}
The British who ruled Mandate Palestine established a prison visiting system that enabled inspection and oversight of carceral conditions by officials and lay representatives. In often contradictory and variegated ways, both the British and their subjects used this system as a political tool. For the British, lay participation in prison visiting was consistent with colonial pursuits such as advancing penal reform, attempting to "civilize" the local population, preserving the colonial difference, pacifying the locals, and co-opting opposition. The colonized employed prison visits for their own conflicting purposes: to advance both national goals and a universal agenda, to defy the colonial difference and to embrace it at the same time. British repurposing of reformist ideology to advance its civilizing mission was thus vulnerable to the claims of the colonized, who employed prison visiting to advance claims for ethnic and national equality, striking at the core principle of colonial difference. By examining the prison visit policy in Mandate Palestine, this article offers a pioneering approach to the political history of the colonial prison and the tension between penal reform and the larger colonial agenda.
\end{abstract}

\section{INTRODUCTION}

This article explores the history of prison visitation in Mandate Palestine. This little-examined history affords a valuable lens through which to view the colonial prison in its wider ideological and political context. The prison visiting system, which enabled the inspection and oversight of carceral conditions by officials and lay representatives, was imported to Mandate Palestine after it was already established in England in the

Orna Alyagon Darr is Associate Professor, Law School, Sapir Academic College; Research Fellow, School of History, University of Haifa, Israel Email: oad@mail.sapir.ac.il

Rachela Er'el is Doctoral Candidate, Faculty of Law, Hebrew University of Jerusalem, Israel Email: rachela.erel@mail.huji.ac.il

The authors thank Anthony Bottoms, Vincent Chiao, Antony Duff, Antje du Bois-Pedain, Shachar Eldar, Miri Gur-Arye, Rinat Kitai-Sangero, Mordechai Kermnitzer, Shai Lavi, Sandra Marshall, Matt Matravers, Dana Pugach, Amit Pundik, Paul Roberts, Boaz Sagero, Anat Scolnicov, Lorenzo Zucca, and Leslie Sebba, the participants of the 2019 Beccaria Workshop at the Institute of Criminology at the University of Cambridge, and the participants of the 2020 Criminal Law Workshop at Hebrew University and the 2020 Colloquium at the law school of Sapir Academic College for their comments on earlier drafts. We would like to thank Yam Traiber and Nir Propper for all their help as research assistants. Our thanks and appreciation go to Dr. Yochai Ben-Ghedalia, director of the Central Archives for the History of the Jewish People, for his assistance with the Magnes Archive. Special thanks are due to four anonymous reviewers and Christopher W. Schmidt for insightful and inspiring comments. This study was supported by the Israel Science Foundation (Grant no. 368/20). Both authors contributed equally to this article. 
early twentieth century (Paterson 1940) and imported to other colonies within the British Empire. ${ }^{1}$

The British completed the occupation of Palestine in 1918. In 1922, the League of Nations granted the British a Mandate to rule Palestine until 1948. One of the first priorities of the Mandate rulers was the construction of police and a prison system. As early as 1921, the British had decreed the inspection of Palestine prisons through visits by administrative and judicial officials. Yet such visits were rare, and, in 1929, high-ranking British figures founded a system of visitation based on lay participation, enabling their local subjects-both Jews and Arabs-to visit prisoners from their own communities. Other British administrators opined that the representatives of the colonized authority were overstepping their role of care for prisoners' welfare and interfering in prison administration. The Prison Visitors' Committee was discontinued in 1930. However, the practice endured, and the lay visitors' power to oversee conditions in Palestine prisons was eventually cast in legislation in 1940.

We argue that, in Palestine, both the British rulers and their subjects used the prison visiting system, in often contradictory and variegated ways, as a political tool. For the British, lay participation in prison visiting was consistent with colonial pursuits such as advancing penal reform and the civilizing mission, preserving the colonial difference, pacifying local subjects, co-opting possible opposition, using the colonized as a resource, and standardizing colonial models of prison systems. In the colonial setting, pursuit of reform and the maintenance of the "rule of colonial difference" exist simultaneously (Kolsky 2005a; Chatterjee 2020). Enlightenment and exploitation, in the words of Ann Laura Stoler $(2009,3)$, "are not mutually exclusive but deeply entangled projects." To explore the complex and ambivalent position that the British held regarding the empowerment of local subjects as prison visitors, this article focuses on Margaret Nixon, Palestine's government welfare inspector, who introduced the British prison visiting system into Palestine in 1929.

The colonized, too, employed prison visits to exert agency in various, sometimes conflicting, ways. They used them to advance both national goals and a universal agenda, to defy the colonial difference and embrace it at the same time. This article demonstrates these complexities by focusing on two local prison visitors. The first is Dr. Yehuda Leib Magnes, a member of the first panel of prison visitors, whose intervention in the 1930 hunger strike by communist prisoners illuminates the intermediary position of visitors chosen from the local elite and how prisoners used the visiting system to exert political power. The second is Rabbi Dr. Kalman Kupfer, whose role as a professional prison visitor in Tel Aviv-Jaffa District in the 1940s gave the Jewish community an opportunity to advance its national goals.

1. According to Howard League, the United Kingdom's (UK) oldest penal reform charity, "it is the common practice in the Crown Colonies to have unofficial prison visitors." Letter from Cicely Craven to Sir Grattan Bushe, May 30, 1938, CO 733-382-10, The National Archives, United Kingdom (TNA). As of August 31, 1938, the Colonial Office suggested a model for the annual reports of the Colonial Prisons Department. This model specifically referenced inspections and visits. "Correspondence and Model Prison Report," Interchange of Colonial Reports, MandatoryOrganizations-SecretaryPolice-000mvyk, Israel State Archives (ISA). On the transplantation of the prison visitation system to India, see India's Prisons Act of 1894, s. 59(25); Devarmani and Mangoli 2015. 
The visitors' grievances and concerns provide valuable empirical evidence of the carceral reality. The visiting system, by definition, assumes that actual conditions of imprisonment can diverge from legal dictates and invites criticism of the official policy or of noncompliance with existing legal standards. The visitors amplify the prisoners' voice and their political claims. Such amplification is exceedingly pronounced when the prison is another terrain for a national or political struggle, as was the case in Mandate Palestine, where the politicization of the governed created a growing population of political prisoners. We therefore suggest that the focus on the institution of prison visiting offers an especially potent perspective not only on the colonial prison in its wider ideological and political context but also on the gap between "law on the books" and "law in action."

By examining the hopes, beliefs, and intentions of the actors involved in the formative stages of the prison visiting system in Mandate Palestine, our study offers a good entry point to the study of broader questions of carceral history in other regions as well. Focusing on the visiting system sheds light on larger questions of colonialism and law: colonial punishment, tensions between the reformist ideology and other colonial policies, politics of difference, and how both the colonizers and the colonized perceived the purpose of legal transplants and their possible uses.

\section{BRITISH PENAL REFORM LEGACY IN COLONIAL CONTEXTS}

This article's focus on the institution of prison visiting affords a new angle on the tension between reformist penology and the goal of maintaining social order, a tension that has been particularly highlighted in postcolonial scholarship on penal history. Earlier histories of England's prisons emphasized a progressive narrative of reformers who were motivated to replace cruel and painful corporal punishments and despicable conditions of imprisonment with more "humane" and modern alternatives (Spierenburg 1998, 68; Gibson 2011, 1045). The beginning of this reform is often associated with John Howard (1777), whose book, The State of the Prisons, exposed the deplorable conditions and poor management in prisons and became the manifesto of prison reform (Fisher 1995, 1236). ${ }^{2}$

This traditional benevolent, "humanistic" narrative has been criticized by historians who have stressed the repressive aspects of the rise of the prison system. Despite the theoretical and regional differences between revisionist historians such as Michel Foucault (1977), David Rothman (1971), and Michael Ignatieff (1978), they all share a more sinister view of prison reform in which the main goal of penal institutions is not

2. The "Howard League for Penal Reform," the UK's oldest penal reform organization, is named after John Howard (Lalli 2000). The meaning of the term "prison reform" and its scholarly theorization have differed across time and regions. Early reformers focused on the institutionalization of prison and penalization, advocating improved conditions of imprisonment, nationalization, and using imprisonment as a criminal punishment (Cooper 1976, 81; McGowen 1995, 79). Quaker reformers active around the turn of the nineteenth century concentrated on the spiritual and sociological salvation of the individual prisoner and advocated goals such as rehabilitation, alternatives to punishment, education, and elimination of corporal punishments (Cooper 1981, 675, 678, 688; McGowen 1995, 86). Benthamites and reformists in the 1830s focused on deterring crime. Inspired by American carceral innovations, they supported solitary confinement, silence, hard labor, and strict discipline (Cooper 1981, 675, 689-90). 
ensuring prisoners' rights but, rather, the exercise of power, which is implemented through intrusive dehumanization, mind and body control, and identity-stripping practices (Gibson 2011, 1044).

Another disenchanted view of the British legacy of reformist penology is found in postcolonial scholarship about the penal system, most noticeably in historiographic studies of Asia and Africa (Arnold 1994; Agozino 2004; Brown 2007; C. Anderson 2008; Stephen 2008; Sherman 2009; Kolsky 2010; Hynd 2011; Moore 2014). Florence Bernault $(2003,4,9)$ argues that colonial prisons did not aim to ensure social harmony or conformity but, rather, to bolster European hegemonical control through the consolidation of racial tensions and inequality. Reformist and liberal ideas were yoked to advance European colonialism by means such as the selective importation of human rights and freedoms, embracing only those deemed applicable to the local subjects and their level of civilization and modernity (Ibhawoh 2008); employing positivist criminology as a way to oppress the colonial subjects (Agozino 2004); establishing a legal penological culture of "New Punitiveness," in which terms such as "crime," "law and order," "inclusion and exclusion," and "rights and duties" were employed by imperial rulers to legitimize their rule (Moore 2014, 31-48); or using transformative rhetoric about prison as a site for instilling European values, while treating prisoners as a source of cheap labor to replace slaves (Berridge 2012). Reformist ideas were used to increase social control of the lower (offending) classes in Europe as well (Foucault 1977, 234), but such usage was much more pronounced in the colonial context, due to differences in power and culture between the rulers and their subjects (Scicluna and Knepper 2008, 517) and the constant tension between reformist impulses and the desire to discipline "others" (McClendon 2018).

Despite its explicit advocacy of humanistic values, in practice, reformist penology nonetheless went hand in hand with the imperial project of control over foreign bodies, as some instances of prison visiting make clear. Anne Schwan (2010) demonstrates such a nexus in the work of Mary Carpenter (1807-77) in colonial India. Late in life, Carpenter, an illustrious prison reformer, made four trips to India between 1866 and 1876, visiting female prisoners there, actively promoting the extension of the reformist ideology outside Europe. In India, Carpenter's reformist agenda was directed at the control of "alien" criminal women. In practice, the language of Christian philanthropy and reformist penology enhanced British rule, and through their activity in the penal sphere, middle-class British women secured influence beyond what could be exerted by male authorities. We suggest that a focus on prison visiting, which encompasses the goals of both penal reform and social order, can shed light on the inherent tension between the goals of reform and other colonial policies.

The history of prison visitors in the British Empire has received only scant academic attention, and only a few scholars have studied the prisons of Mandate Palestine, most of them incidentally. Existing scholarship mentions the tortures inflicted on detained suspects and their petitions through the Anglican Mission, the sexual maltreatment of women who were arrested and detained by the British security forces (Hughes 2009, 17; 2013, 705; 2019, 523-56), institutional coping with mentally ill female inmates in Mandate Palestine's prisons (Zalashik and Davidovitch 2011), and internal arguments within the British administration regarding the hospitalization of "criminal lunatics," incidentally mentioning complaints about the carceral conditions 
of the mentally ill and other prisoners (Wilson 2019). Some accounts of insurgency in Mandate Palestine mention in passing the effect that punishments and imprisonment had on the crystallization of national consciousness and on the political role of prisons, but they dwell less on penal or criminological aspects (Miller 1985; Kolinsky 1993; Lockman 1996; Louis 2006, 391; Golan 2014; Greene et al. 2017; Smith 2017).

An outstanding exception is an article by Joshua Kaspi (1984) that reviews relevant legislation and maps the prisons, imprisonment camps, and detention facilities in Mandate Palestine. Kaspi provides basic facts about the conditions of incarceration, the categories of prisoners, prisoners' labor, the marks system, and disciplinary measures. While he refers to the personal visits of friends and family and clergy who conducted prayers, he makes no mention of prison visitors. Our focus on prison visitors, especially where the visitors are themselves members of the colonized, supplements the existing literature with a methodology suitable for exploring the tension between reform and other colonial policies as well as the penal experience from the perspective of colonial prisoners. Studies that trace the subalterns' agency find that the colonial prisoners were not necessarily the "docile bodies" that Foucault described. Colonial prisons were also the sites of sporadic defiance, and behind the façade of isolation, prison was integral to wider culture and social dynamics (Arnold 1994). Colonial prisoners were active in riots, escapes, and dealings with collaborating wardens and developed resistance networks (Fourchard 2003, 142-46; Berridge 2012) and turned prisons into sites for the formation of a national identity and fostering of political consciousness, organization, and resistance (Zinoman 2001, 2; Ibhawoh 2008, 19).

Recent scholarship inspects penal regimes within a broader political, administrative, and societal context and a wide range of coercive practices (Paton 2004; D. Anderson 2005; C. Anderson 2007). ${ }^{3}$ The present study of prison visitors further contributes to "colonial punishment" scholarship, a theoretical framework that explores various and conflicting perspectives of both colonized and colonizers on punishments and penal regimes as part of a broader societal and political context and how both deployed the inherent tension between reformist penology and the maintenance of social order.

\section{SOURCES}

The bulk of the materials on which this article is based were found in archives. The National Archives of the United Kingdom and the Israel National Archives contain mainly correspondence between British administrators-both in Palestine's government and the Colonial Office-and various local players and official reports. The documents often expose not only the official policies but also nuanced and sometimes conflicting colonial stands. Major municipal archives in Israel (Tel Aviv, Haifa, and Jerusalem) expose the minute details of the Jewish community's organized and semi-organized attempts to influence the authorities' treatment of prisoners, internal controversies, and the role played by prisoners' aid associations. Another significant source of archival material was the Magnes Archive, a sub-archive of the Central Archives for the History

3. For disciplinary taxonomies, see Hynd 2011, 432; Sherman 2009, 650-60. 
of the Jewish People in Jerusalem. This archive contains the papers of Judah Leib Magnes, a prominent member of the Jewish community, who was well connected with high-ranking British figures and a member of Palestine's first panel of prison visitors. Magnes was an avid documentarist who kept any relevant letter, pamphlet, newspaper clip, and note. The documents reflect his intermediary position between British circles and prisoners and open a window to diverse perspectives. They include letters from prisoners and their family members, correspondence with the authorities, and documentation of negotiations with the different parties in moments of conflict. In addition, we used the contemporary press and pamphlets, protocols of city council meetings, and memoirs. ${ }^{4}$ Our hope of finding interviewees who specifically engaged in the practice of prison visiting in one way or another and could shed light on actual practices was dashed, and we therefore relied on interview-based secondary literature. ${ }^{5}$

We analyzed both the content and rhetoric of the primary sources. Our reading assumes that colonial practitioners diverged in sensibilities, dispositions, and beliefs and that the archives do not represent a static entity but, rather, as Stoler (2009, 32-33) articulates, contain "restless realignments and readjustments of people and the beliefs to which they were tethered, as spaces in which the senses and the affective course through the seeming abstractions of political rationalities." By attentive reading of these primary documents, first "along the grain" (53), we sought to capture the "grain" of the British heritage of the prison visitors' institution. We then continued by reading the materials "against the grain" (Guha 1997; Kolsky 2005b, 706; Stoler 2009, 46; Prasad 2012, 20-22), aiming to reconstruct the subaltern voices and trace the agency of Palestine's colonial subjects and to highlight the space and tensions between various and conflicting visions of the institution of prison visitors, the colonial conditions, and the gap between idealized values of the official acts and policy and actual practices.

\section{PRISON INSPECTION IN MANDATE PALESTINE}

\section{Legal Background}

In 1922, the League of Nations officially approved the establishment of a mandate system, in which the territories occupied in the First World War were to be governed by England and France under international supervision. The ultimate goal of the mandate system was to bring the inhabitants to self-rule. The League of Nations entrusted the rule of Palestine to the British government. ${ }^{6}$ Article 2 of the charter of the

4. While the memoirs provide important background about life in Palestine prisons from the prisoners' perspectives, they rarely discuss the institution of prison visitors per se.

5. For example, Golan 2014. Finding interviewees with a good recollection of the Palestine police in general is still possible. See the Palestine Police Oral History Project held by the Middle East Centre Archive, https://www.sant.ox.ac.uk/research-centres/middle-east-centre/mec-archive/meca-palestine-policeoral-history.

6. The two key legal documents that constituted the rules of the mandate-the League of Nations Mandate for Palestine and the British Order-in-Council-began to be drafted in 1919 and were published in 1922 (Strawson 2010). 
Palestine Mandate provided, inter alia, that the British were required to develop selfgoverning institutions. A judicial system, police, and prisons were essential to the goal of keeping order. The establishment of a prison system in Palestine even preceded the official formation of the mandate. Shortly after the British conquered the area of Palestine in 1918, they began to regulate the arrest and incarceration of people. The Occupied Enemy Territory Administration promulgated orders and ordinances, including with respect to prisons and detention (Kaspi 1984, 141-43). The British built a central prison in Jerusalem and used other facilities across the country.

In 1921, while still ruling Palestine as an occupying military force, the British passed the Prison Ordinance regulating the administration of prisons, which enabled the inspector general of police and prisons, with the approval of the high commissioner, to make rules regarding a wide range of matters, including letters, visits to prisoners, and inspection by "visiting authorities." People who were allowed to visit prisoners under the British legislation can be divided into three categories. The first were those visiting individual prisoners. While awaiting trial, prisoners were allowed to communicate with their legal advisers and have weekly visits from friends and relatives. ${ }^{8}$ Convicted prisoners were allowed to receive visits from friends and relatives after the completion of the first three months of their sentence, and every two months thereafter, within the sight and hearing of a prison officer. ${ }^{9}$ Consular representatives, however, were allowed to interview foreign prisoners outside the hearing of the prison officers. ${ }^{10}$ Seriously ill prisoners could receive visits from friends and relatives. ${ }^{11}$ Young offenders detained at a reformatory school could have half-hour weekly visits with their parents, subject to the discretion of the medical officer and at the discretion of the officer in charge. ${ }^{12}$ All of these visitors could be searched. The second category consisted of religious figures, who could visit prisoners belonging to their religious denomination and hold services. ${ }^{13}$ The British sometimes called them "unofficial" visitors to distinguish them from officials. The third category was composed of ex-officio visitors and civilian volunteers who were allowed to visit a group of prisoners rather than particular individuals. ${ }^{14}$ The first Prison

7. Ordinance to Make Provision for the Administration of Prisons and the Discipline of Prisoners (Prison Ordinance 1921), 1921, paras. 6, 12(2)(f).

8. Regulations Made under Section 4(a)(vi) of the Prison Ordinance 1921 (Prison Regulations), 1924, paras. 1, 259. Prison Ordinance 1921, para. 12(2)(f) provided that the inspector general, with the approval of the high commissioner, could make rules with respect to visits. Later regulations set forth the conditions for such visits. Palestine Police and Prisons, Prison Regulations, 1925, paras. 257, 260-63, 266-67. Visits were to occur "on the day of rest" meaning that visitors of different religious visited on different days (Muslims on Fridays, Jews on Saturdays, and Christians on Sundays). Prison Ordinance no. 2, 1940, para. 52(3).

9. Prison Regulations, paras. 260. 263, 266; Prison Ordinance no. 2, para. 52(1).

10. Amendment to Rules Made by the Inspector General of Police and Prisons under Section 4, Palestine Gazette no. 583, 1936.

11. Prison Ordinance no. 2, para. 52(2).

12. Regulations for Reformatory Schools made by the Commandant of Police under Section 4 of the Prisons Ordinance 1921, 1932, paras. 35(1), (2).

13. Prison Regulations, paras. 252-53; Prison Ordinance no. 2, para. 52(4).

14. The contemporary English system encompassed three categories of visitors: (1) officials who were expected to inspect and supervise carceral conditions as part of their professional duties; (2) boards of visitors with two lay magistrates and other community members who supervised the running of the prisons, heard the inmates' complaints, and also acted as a tribunal for the more serious disciplinary offences committed by the prisoners; (3) respectable community volunteers, selected and appointed by the Prison Commission. 
Ordinance in 1921 established a category of "visiting authorities," which included only ex-officio visitors. ${ }^{15}$ The district commissioner was entitled to inspect and visit any prison within his district at all times and had free access to every part of the prison and to every prisoner and all records. Any British judge, Jewish and Arab district court judges, and any principal medical or health officer could also visit at any time. These visitors had to inform the inspector general of their visit and could make observations and recommendations if they so wished.

In 1940, a second Prison Ordinance redefined the category of official visitors. Now called "visiting justices," the category was broadened to include not only ex-officio visitors ${ }^{16}$ but also "fit and proper persons" appointed by the high commissioner to individual prisons. The open-ended definition enabled the appointment of lay representatives of the local subjects. In internal correspondence, the British sometimes referred to these civilian volunteers as "unofficial visitors" (which was somewhat misleading terminology, as all visitors had to be officially approved). ${ }^{17}$ All visiting justices, civilians included, could inspect all books and records as well as each and every ward, yard, and cell, see every prisoner, test the quality of the prisoners' food, and ascertain adherence to the rules and regulations. At the conclusion of their visits, every visiting justice had to enter any remarks, suggestions, or recommendations in a book kept for this purpose. Only male visiting justices could try prisoners for prison offences, summon witnesses, and administer oaths. Female visitors could be appointed only for the part of the prison in which female prisoners were detained. ${ }^{18}$ The third Prison Ordinance, which was released in 1946, preserved this arrangement, with a single new limitation that restricted female visitors to areas designated for female prisoners. ${ }^{19}$

While lay visiting was formally sanctioned by the 1940 Prison Ordinance, this practice was established eleven years earlier at the initiative and with the support of British officials, who not only allowed outsiders to inspect the prisons but also made sure the visitors included the representatives of their local colonial subjects. The following subsection investigates the creation of this institution and discusses the possible ideas and practices that influenced the British choice to adopt this practice.

\section{The Rise, Fall, and Rebirth of Lay Visiting in Mandate Palestine Prisons}

The story of the establishment of the Prison Visiting Committee in 1929, its discontinuation the following year, and its subsequent revival conveys the intricacy of British attitudes toward this practice. At first, the practice emerged as a project of reform. The Mandate officials were aware of the severity of the carceral conditions in Palestine's prisons. In 1928, the high commissioner asked Margaret Nixon, the

These men and women made weekly visits to a designated group of prisoners in order to maintain their contact with normative society and help them reenter society at the end of their term.

15. Prison Ordinance 1921, para. 6(2).

16. Under the second Prison Ordinance, the composition of the ex-officio visitors changed. It included members of the Executive Council and judges of the Supreme Court who could visit all prisons in Palestine, and the district commissioner, who could visit all prisons in his district.

17. In current practice in Israel and England, these visitors are now termed "official visitors."

18. Prison Ordinance no. 2, paras. 21, 56.

19. Prison Ordinance no. 3, 1946, para. 5(3). 
government welfare inspector, to write a report on prisons and lockups in Palestine. Before her appointment as government welfare inspector, Nixon had served as the superintendent of all women convicts in Palestine (Rozin 2016, 21). Despite some positive comments and references to the differences between the carceral facilities, Nixon's report was quite critical of the physical conditions, overcrowding, poor hygiene, lack of running water, poor ventilation, dampness, and other shortcomings of the Palestine prisons. ${ }^{20}$

One of Nixon's major critiques pertained to visits. Although the 1921 Prison Ordinance set forth that Palestine's prisons should be inspected by ex-officio visitors, Nixon observed the inadequacy of that practice. For example, she noted that except for police officers and doctors, very few people visited the Central Prison in Jerusalem. Similarly, few officials ever visited the Acre Prison, one "notable exception being the District Officer of Nazareth who visits quite regularly and knows every prisoner. The Officer in charge mentioned the good effect this had on the men." The situation was no better at the Howard Home, a reformatory institution for boys, where no visits took place except for those by an occasional official visitor and the superintendents. Nixon opined that this lack of visitors made it difficult to find employment "for lads who have no home to which they can return as no one takes any interest in them." In Nixon's view, the purpose of the visits by the ex-officio visitors was not rehabilitation. In contrast, in the girls' home that was managed by Nixon herself, care was taken that each and every girl would return either to her family or to a prearranged job. In addition, "[t]he Social Services Association forms a band of visitors who interest themselves in the welfare of these girls." 21

Nixon recommended establishing "a panel of responsible voluntary visitors, men and woman" who would be appointed in each large detention center and "would undertake to make regular visits and to interest themselves in the general welfare of the prisoners. This applies very specially to young offenders. ... Many of the lads come from very unsatisfactory surroundings and often slip back into the same vicious environment for want of friendly assistance at the time of their release." She also recommended that the short sentences of young offenders be replaced with a system of probation or a term of a minimum of one to two years in a reformatory. ${ }^{22}$

As Anne Schwan's (2010, 110) research demonstrates, the work of sincerely committed and "progressive" reformers can be entangled with the imperial project. Notwithstanding the genuineness of their advocates, reform projects are also compatible with political goals, such as the civilizing mission and the maintenance of the colonial difference. Nixon was a sincere advocate of penal reform. Nonetheless, her report also supported colonial difference by calling for privileged treatment of "obviously European" prisoners. Nixon opined that standard conditions of imprisonment without beds, chairs, or tables, and with "ordinary prison food," were unsuitable for such prisoners, as "[t]hese are real hardships to educated men and women used to a European standard of living ... no good can possibly accrue from treatment of this sort." 23

20. Nixon's Report, July 1928, 3, MandatoryOrganizations-ChiefSecretary-000x6fb, ISA.

21. Nixon's Report, 4-5.

22. Nixon's Report, 6.

23. Nixon's Report, 5. 
In reference to illegal immigrants and communist prisoners, who were most likely Jews of European descent, she wrote: "They have separate quarters in the prison, they wear their own clothes, have books and newspapers, they can study, and do their own needlework, and have excellent European food" (Nixon 1935, 136). The British administration embraced Nixon's recommendations and took steps to improve the conditions of imprisonment. ${ }^{24}$

One major reform that the British adopted was the formation of a prison visiting system that enabled local subjects, appointed by the high commissioner, to inspect Palestine prisons. This warm welcome suggests that the British saw political advantage in prison visitation policy. Reforms such as these positioned the British as the bearers of progress and humanity to an underdeveloped region and therefore provided cultural and political rationale for their "civilizing mission." Nevertheless, the new prison visiting policy was a notable departure from existing practices. Unlike modern European prisons, colonial prisons did not rest on social consensus but, rather, attempted to reinforce the rulers' authority (Gibson 2011, 1053). In other law enforcement-related areas, the British limited the lay involvement of their subjects. They deliberately refrained from transplanting the jury system into Palestine, and, until 1936, the testimony of a single witness did not suffice to serve as a basis for judgment unless it was corroborated (Likhovski 2006, 30). ${ }^{25}$ The establishment of a system allowing subalterns to voice criticism of prisons was aberrational in the context of colonial justice.

Pursuant to correspondence between Norman Bentwich, Palestine's first attorney general, and the commandant of police and prisons, the Prison Visitors' Committee was formed, ${ }^{26}$ headed by Bentwich himself and including Nixon as a member. ${ }^{27}$ At its first meeting on January 31, 1929, the committee appointed five men as "prison visitors." Two of them were Arab, Ismail Bey Husseini ${ }^{28}$ and Ruhi Bey Abdul Hadi; ${ }^{29}$ two were

24. For example, they immediately dealt with the shortage of water in the lockups of Tiberias and Jaffa. The British administration dubbed the report "helpful and constructive." Letter from Acting Chief Secretary E. Mills, August 19, 1928, image 7, MandatoryOrganizations-ChiefSecretary-000x6fb, ISA.

25. The reception of the jury system across the British Empire was partial (Knox-Mawer 1958, 161).

26. Such an arrangement was not unique to Palestine. See, for example, Irish Prisons (Visiting Committees) Act, 1925, paras. 2, 3, http://www.irishstatutebook.ie/eli/1925/act/11/enacted/en/print\#sec1. Ireland preceded England in establishing an inspection system (Stockdale 1983, 214). Resemblance in format, however, does not necessarily entail similar cultural meaning. For more about the roots of prison visiting in Ireland, see Luddy 1988.

27. Other members were Mrs. R. McInnes, the widow of a former Anglican bishop and a welfare worker, Mrs. F. T. Ellis, Dr. H. Kohn, Dr. M. Schwabe, Mr. G. Botagy, and Mr. Edwin Herbert Samuel.

28. Ismail Bey Husseini (1860-1945) was born to a wealthy and prominent Arab family in Jerusalem. He maintained amicable relationship with the authorities during the Ottoman period and under British rule. He was active in political discussions about the Palestinian position on the Balfour declaration and the future of Palestine. In 1918, he welcomed the Zionist mission headed by Chaim Weizmann. He was a member of the British Board of Advisors established in 1923 but resigned after facing criticism from most Palestinian notables. He owned lands and was a businessman. With Jewish counterparts, he was involved in developing a hotel and spa on the Dead Sea shore. The hotel housed a casino that was denounced by Arab nationalists as "including everything that is forbidden for Muslims" (Tal-Krispin 2010, 264).

29. Ruhi Bey Abdul Hadi (1885-1954), born in Jenin, graduated from the Institute of Law in Istanbul in 1908. Under Mandate rule, he fulfilled senior administrative positions in the Palestine government. In 1921, he was elected secretary of the first Palestinian delegation to London but eventually did not attend 
Jewish, Dr. Judah Leib Magnes and J. Meyuhas; ${ }^{30}$ and one was American, Edward Williams Blatchford. ${ }^{31}$ The design of imprisonment, which maintained the differences and hierarchies between European and non-European locals, Jews and Arabs, and males and females was reflected in the visiting system. Its design reflected ethno-national considerations and bolstered "the rule of colonial difference." Arabs were to visit Arabs, Jews to visit Jews, in a divide-and-rule scheme. ${ }^{32}$

The composition of the visitors panel was also compatible with political ends such as the co-optation and pacification of the locals. The risk that the visiting system would expose the British to criticism by their subjects could be attenuated if the mission was placed on the shoulders of community representatives who the British considered trustworthy. The chosen visitors were leading figures in their community, yet they also moved in high-ranking English circles and were forthcoming in their attitude toward their ethnic counterparts and, therefore, occasional targets of nationalist criticism from within their communities. ${ }^{33}$ Ruhi Bey Abdul Hadi was even a government employee (an assistant secretary at the Chief Secretary's Office at the time). By selecting and nominating them, the British signaled the visitor's esteemed position. However, lay participation in Palestine's law enforcement was designed to circumvent any actual influence of the subjects on adjudication, the quintessential example being the exclusion of the jury system. Such participation was limited to the protection of the rights of those already incarcerated and detained by the British justice system. Though not a trivial privilege, it was intended to be limited to social, rather than adjudicatory, aspects.

for personal reasons. After the termination of the Mandate, he held ministerial posts in Jordan and served as Jordan's justice minister. "PASSIA," accessed 5 October 2021, http://passia.1885-1954/personalities/105.

30. Joseph Meyuhas (1868-1942) was born in Jerusalem to a Sephardi rabbinical family. He was an educator, author, and researcher of Arabic folklore. He was one of the leaders of the Jewish community in the Mandate era and a member of the Jewish National Council. See Ben Yehuda Project, https://benyehuda. org/author/90; Encyclopaedia of the Founders and Builders of Israel, 101, http://www.tidhar.tourolib.org/tidhar/ view $/ 1 / 101$ ? search[] = \%D7\%99\%D7\%95\%D7\%A1\%D7\%A3\&search[] = \%D7\%9E\%D7\%99\%D7\%95\% D7\%97\%D7\%A1.

31. Edward Williams (Ned) Blatchford (1868-1956) was born in Chicago and a graduate of Amherst College. In 1918, he travelled to London with the Young Men's Christian Association's National War Work Council and later transitioned to relief work with war orphans in the Middle East. He arrived in Jerusalem in 1922 where he served with the US Consulate and was the director for Palestine of the Near East Relief. In his charity work with orphans, he managed to engage the leaders of the Muslim, Christian, and Jewish communities in Jerusalem as well as high-ranking British administrators (Kalbian 2018). Minutes of the First Meeting of the Prison Visitors' Committee Held at Government Offices, Jerusalem, January 31, 1929, Privatecollections-EdwinSamuel-00017zs, ISA.

32. The binational representation does not rule out the British distinction between Palestine's Jews and Arabs, as is evident from the following quote from Norman Bentwich $(1938,79)$ : "It would be hard to lay down any code which would be equally appropriate to the very progressive and completely Westernized Jewish population of Palestine, the Arab fellahin and the tribal Arabs who are still in the conditions of our Middle Ages."

33. Ismail Bey Husseini's status and good relationship with the British made him a welcome guest at events such as the royal visit of Amir Abdullah and Abbas Hilmi Pasha at the Government House (Palestine Post 1935, 5). He was engaged in other welfare projects—-for example, he was a member of a relief committee formed after a 1927 earthquake (Blatchford, another prison visitor, was also a member) (Palestine Bulletin 1928, 3). Like Ismail Bey Husseini, Ruhi Bey Abdul Hadi was a welcome guest at events such as a dinner party held by the high commissioner (Palestine Post 1934, 5). Magnes had a close friendship with Bentwich. The tone of their notes to each other is unmistakably warm. Bentwich later became the chair of international relations at the Hebrew University (1932-51) and Magnes's biographer (Bentwich 1954). 
Edwin Samuel, the son of a former high commissioner who was also serving in the Palestine government, was temporarily named honorary secretary and put in charge of informing both the police authorities and the visitors of the visitors' list of duties and prison regulations, and the superintendent of the Jerusalem Central Prison on whom each visitor would call. Ruhi Bey Abdul Hadi was asked to investigate whether the balance of the Men's Social Services Association could be handed over to the committee to assist prisoners' families in case of need. The group decided to hold quarterly meetings and establish a subcommittee (whose members would be Nixon, Blatchford, and Samuel) to work out a system of visiting the Howard Home at Tulkarem. Subsequently, Samuel met with Mr. Frew, the superintendent of the Central Prison, to design the visiting operation. ${ }^{34}$ The meeting seems to have been friendly and cooperative, yet, nonetheless, the agreements narrowed down the visitors' access and designated a nonpolitical role for them. It was agreed that "[t]he allocation of a number of prisoners to each Visitor is not the best method." Instead, the superintendent would keep a register of prisoners who were "particularly dejected," or whose families appeared to be in need, or who were expected to be released shortly after serving a sentence of five years or more and needed help finding employment. This arrangement, which diverged from the English pattern, increased the prison service's control over which prisoners the visitors could see. The agreed-upon points imply that the committee perceived visitation as a welfare measure, designed to keep the inmates occupied in a positive manner and prepare them for their reentry into society.

The arrangement also reflects the superintendent's hope of encouraging the visitors to help the prison. Thus, the superintendent raised the issue of the limited space in the prison's workshops (such as carpentry, ironworks, cobbling, weaving, tailoring, and basket and mat making). He explained that since brush making is an activity that could take place in the prisoners' own cells, "it would be of great help if the Prison Visitors Committee could make it possible to provide an instructor for say, two hours an afternoon, three times a week" for about fifty prisoners. He also stated that it would be "of great assistance" if the visitors could not only lend books to prisoners but also give books to the prison library. Specifically requested were books in Arabic or Hebrew and illustrated papers "of high standard" for the illiterate prisoners. Books, it was stated, would "also be appreciated in the Wardens' Mess." The superintendent's hope seems to reflect institutional considerations and not merely a reformist ideology. The British attempt to use the volunteering visitors as a resource for prison management in raising funds, donating books, and providing workshop instructors shored up the visitors' social position, transforming them into benefactors of their rulers. ${ }^{35}$

The British scheme of visits in the prisons of Palestine reflected several themes of the larger penal reform movement of this period. It drew on religious sentiments and highlighted the importance of religious instruction and practice. The 1921 Prison Ordinance sanctioned visits by chaplains of all major denominations. ${ }^{36}$ This arrangement acknowledged the importance of "spiritual maintenance" and the view of religion as a basic human right that persists even under conditions of imprisonment. It is

34. Record of a conversation that took place on February 21, 1929.

35. Record of a conversation that took place on February 21, 1929.

36. Prison Ordinance 1921, para. 12(1). 
noteworthy that Edward Williams Blatchford, an American evangelist who was appointed the American vice-consul for religious affairs in 1929, was one of the first prison visitors (Kalbian 2018, 56). In Palestine, however, religion and nationality were intertwined. Judaism is both a nation and a religion, and the visiting rabbis advocated national causes as well. Another source of influence was Howardian reformist humanitarianism, which promoted regular inspections to combat specific abuses. In Nixon's vision, visitation would serve not only to improve the conditions of imprisonment but also to rehabilitate. Her view of rehabilitation was integrated into a broader professional ethos of advancing welfare, with an emphasis on protecting the vulnerable.

Nixon's report emphasizes the importance of reaching out to the prisoners and creating contacts that would assist released prisoners upon their reentry into society. However, the British intention to promote the rehabilitation of Palestine's prisoners through visitation was not backed by institutional arrangements. The Prison Visitors' Committee created a practice of inspections that did not extend beyond the period of incarceration. The visitors did not deal with the housing or job placement of released prisoners. ${ }^{37}$ The members of the Prison Visitors' Committee took active part in the visits. Thirty visits were paid to the Jerusalem Central Prison between March and June $1929 .{ }^{38}$ The visitors commented on prisoners' verbal and physical abuse, raised funds, and assisted prisons with library books and instruction, but they also discussed matters of prison administration and policy, such as the imprisonment of juveniles, the Penal Labour Ordinance, the necessity of salaried probation officers and juvenile courts, the establishment of a Borstal Institution, and separate accommodation for "criminal lunatics."

The prison visiting institution was established with the support of high-ranking members of the British administration in Mandate Palestine. ${ }^{40}$ The visitors enjoyed the cooperation of the police and judges. High-ranking police officer Arthur Tyrell Blackett and the District Judge de Freitas even joined the committee at its second meeting. ${ }^{41}$ However, not all members of the British administration were supportive, and some even regarded the practice as a threat or nuisance. In addition, if there was ever a hope that the visitors' project would confine itself to the prisoners' welfare, the British soon realized this was not the case. In a letter sent to the Colonial Office in 1939, Deputy Chief Secretary of the Government of Palestine Sydney Moody stated that the committee's "brief, not very happy, career" lasted just one year. He described the committee's work in an unmistakably resentful tone. Its purpose, Moody claimed, was "organizing sociological work in connection with the inmates of the prisons and their dependents." The practice soon spilled over into a critique of the Mandate penal system, as the committee "proved unable to resist a tendency not to restrict itself to

37. An exceptional post-imprisonment assistance, funds for a railway ticket to a released prisoner who resided in Egypt, was approved by the committee in its second meeting. Minutes of the Second Meeting of the Prison Visitors' Committee held at Government Offices, Jerusalem, June 18, 1929, Judah Leib Magnes Papers 1890-1948, P3-2306, Central Archives for the History of the Jewish People (CAHJP).

38. Minutes of the Second Meeting of the Prison Visitors' Committee held at Government Offices, Jerusalem, June 28, 1929, 1, Judah Leib Magnes Papers 1890-1948.

39. Minutes of the Second Meeting, 1.

40. The germination of penal reform in governmental circles rather than due to popular pressures (as was the case in England) appeared in other colonial contexts as well. See, for example, Arnold 1994.

41. Minutes of the Second Meeting, 1. 
bona fide sociological work but rather to concern itself with questions of prison administration." 42

The next section focuses on an episode that occurred in 1930 at around the time the British put visitations on hold out of fear that visitors were overstepping the role of pure social work. This episode demonstrates the realization of British fears that the practice of visiting could turn out to be politically costly and that, despite their reluctance to empower their subjects to handle matters of prison administration, they sometimes depended on their mediation in volatile political conflicts.

\section{J. L. Magnes, a Prison Visitor in Action}

Like the British, the colonized subjects made political use of the visitation system. Prison visitation enabled the colonized to exert agency and gain political achievements, as demonstrated in the following episode. Judah Leib Magnes was born in Oakland, California, in 1878 and received his doctoral degree from Heidelberg University in Germany. He was an American Zionist leader and a Reform rabbi and immigrated to Palestine in 1922. Magnes was among the founders of the Hebrew University in Jerusalem and served as its chancellor from its establishment in 1925. While serving as chancellor, he refrained from open political activity. Although he sympathized with the ideology of Brit Shalom, a movement that was founded by Zionist intellectuals and promoted binational and equal Jewish-Arab autonomy under the British Mandate, he was never an official member of this group (Barak-Gorodetsky 2018, 17). Magnes was chosen as a member of the first panel of visitors. In addition to his humanistic worldview and prominent status in the Palestine Jewish community, he was also a personal friend of Norman Bentwich, Palestine's attorney general and chair of the Prison Visitors Committee. Our focus in this article is on Magnes's intervention, as a diligent and committed prison visitor, in the 1930 hunger strike of the communist prisoners.

By 1930, the Jewish political prisoners had successfully fought against oppressive practices such as the requirement to bow before police and prison officers and wardens and forced hard labor as punishment. In early 1930, the British reinstated hard labor but only for Arab political prisoners. ${ }^{43}$ Ali Abd Al Halim and Yussef Ahmad Khalaf, both members of the Communist Party, were sent to labor camps after they refused to bow before prison officers and wardens, an event that ignited tense conflict and manifestations of solidarity by the Jewish political prisoners. On May 3, 1930, the prisoners sent an ultimatum to the inspector general of police and prisons and the high commissioner demanding the abolishment of hard labor and a list of other demands. ${ }^{44}$ Unless these

42. Letter by S. Moody to H. F. Downie at the Colonial Office, January 11, 1939, CO 733-405-8, TNA.

43. Undated Communist Party pamphlet titled "The Barbarian Regime," P3-2307, CAHJP.

44. The other demands included revision of the law about the imprisonment conditions of political prisoners such as beds, tables, latrines, the poor quality of their food, and the desire to be assigned separate rooms. They also demanded the abolition of physical punishment and the right of access to books and newspapers; the annulment of executions of all those imprisoned in the wake of the August disturbances, both Jews and Arabs; the release of prisoners on their own recognizance; and the release of all those detained without trial. Letter from the Jerusalem Committee of Red Aid to Dr. Magnes, May 6, 1930, P3-2307, CAHJP (in Hebrew). 
demands were met by noon of May 5, the ultimatum stated, all political prisoners in Palestine would begin a general hunger strike.

As soon as the hunger strike broke out, the Jerusalem board of the Red Aid notified Magnes. Magnes sent Bentwich a note, asking whether he knew of the strike and the prisoners' demands. Bentwich replied: "I heard of this and I do not think anything is to be done." 45 The political pressure exerted by the prisoners reached beyond the borders of Palestine. F. Seymour Cocks, a Labour member of parliament, raised the issue in the House of Commons (Palestine Bulletin 1930, 2). On May 13, 1930, the striking prisoners sent a letter to the Prison Visiting Committee and to Magnes, demanding the abolishment of forced hard labor for all political prisoners and the return of Ali and Yussef from the labor camps. ${ }^{46}$ The prisoners reported that extreme measures were being taken against the striking prisoners, including solitary confinement.

The political prisoners attacked the Prison Visiting Committee, criticizing them as a legitimization device for the colonial regime, a "façade" behind which the authorities responsible for the abusive treatment of political prisoners could hide. They demanded the following:

(1) You accept upon yourselves through Dr. Magnes the negotiations between us and the government authorities regarding a special regime subsequent to Dr. Magnes being officially appointed by the government to act as a proxy; (2) You shall publish all of the government's concessions as well as all of the terms of the negotiations in the newspapers with your signature; any negotiation is contingent on orders from the relevant authorities to return comrades Ali Abd Al Halim and Yussef Hamad Khalaf from forced labour. If these conditions are met we will cease the hunger strike immediately! ... Our opinion is that, should you acknowledge that you are unable to obtain even these minimal conditions to stop the hunger strike, you should immediately disband the "Prison Visitors Committee" and announce the disbandment and its reasons in the press. This is a necessary step for you not to be further used as a tool in the hands of the government to enforce its inhuman behaviour towards the political prisoners, using fictive institutions such as yours! We must clarify that should you avoid complying with these requests. ... we and all honest citizens would regard this as a deliberate refusal to help us achieve a revision of the barbarian regime of the Palestine prisons, and as an indication of your fear of exposing the government's vicious schemes. ${ }^{47}$

This letter reveals ambivalence toward the prison visiting program. The representatives of the communist prisoners requested the help of the Prison Visiting Committee and insisted that Magnes, one of its members, be personally entrusted with the negotiation (possibly on account of his socialist views). However, they also expressed their suspicion that prison visiting was merely a smokescreen, a means of pacifying the local communities while treating their prisoners inhumanly.

45. A note found in P3-2307, CAHJP.

46. Letter on behalf of all striking political prisoners, May 13, 1930, P3-2307, CAHJP.

47. Letter on behalf of all striking prisoners (translated from Hebrew by the authors). 
The British authorities authorized Magnes to negotiate between the strikers and prison management. ${ }^{48}$ Although some of the British preferred limiting visitors to "social work" practice, in this crisis, they entrusted the task of political negotiation to a prison visitor. Magnes acted promptly. The following day, May 14, he visited the forty-four prisoners and reached an agreement to end their hunger strike. The prisoners declared that they were ending the hunger strike based on Magnes's statements that Yussef and Ali would be transferred back from the labor camps and that the government would revise the regulations regarding the standards of imprisonment of political prisoners. ${ }^{49}$ Magnes reported that he had clarified to the strikers that, while the repeal of forced labor for political prisoners could occur only through legislation, the government would give sympathetic consideration to regulations excepting prisoners who had been sentenced solely for membership in illegal societies, possession of illegal literature, or illegal assembly from forced labor.

Magnes maneuvered diplomatically between the parties. To the British authorities, he reported that he had explained to the strikers that their demands could be met only by legislation, thus assuring them he was preserving their interests. To the commandant of the police, Magnes made a powerful presentation of the rationale behind the prisoners' demands. From their perspective, Magnes explained, political prisoners cannot be compared to criminals such as thieves or wife beaters:

They are law breakers in the sense that they have illegal opinions and belong to illegal societies and possess illegal literature. Whereas this is a crime in accordance with the laws of Palestine, it is not, in their opinion, a crime that should bring upon them the necessity of forced labour, forced labour being, so they contend, something to which criminals in an ordinary sense are condemned. ${ }^{50}$

Magnes also updated the commandant of the police and prisons regarding the concession he had made on behalf of the Mandate authorities - namely, that the "special treatment" of prisoners would be applied "without distinction to creed, nationality or social position." 51 The "special treatment" alluded to the colonial distinction between "natives" and European prisoners. In the colonial framework, only the latter, who were presumably more educated and refined, deserved Westernized imprisonment conditions. The elements of the "special treatment" detailed by Magnes included the timely delivery of censored newspapers and books, materials for the writing of books and essays, chess sets, toilets (non-squatting) and bathing equipment in prison (Jaffa prisoners were taken handcuffed to the sea), and smoking.

As this episode indicates, visitors' advocacy for prisoners' welfare cannot be separated from political debates. Political causes were embedded in Magnes's actions to improve the conditions of incarceration. One goal was the preferential treatment of political prisoners. Another was abolishing discrimination between prisoners. In

48. Telephone message to Dr. Magnes, signed by FF, May 13, 1930, P3-2307, CAHJP.

49. Letter from Magnes to the Commandant, May 15, 1930, P3-2307, CAHJP.

50. Letter from Magnes to the Commandant, May 15, 1930.

51. Letter from Magnes to the Commandant, May 15, 1930. 
practice, this meant treating educated Arab political prisoners the same as foreign European citizens. The demand for equal treatment of both Arab and Jewish prisoners went against the colonial "divide and rule" practice, which distinguished and discriminated between colonial subjects on an ethno-national basis. The demand for equality was nevertheless limited, as the struggle was not aimed at equality for all prisoners, political and criminal alike. The strikers implicitly accepted a distinction based on culture and education as justification for differential imprisonment conditions. In accepting this distinction, the striking prisoners were simultaneously defying and advancing the colonial difference.

In his letter to the commandant of the police, Magnes commended the authorities for considering the formation of a "Prisoner Committee" that "might employ a trustworthy man whose duty it would be to visit prisoners, to talk to them, explain things to them and hear what they have to say. I am sure that much trouble could be avoided in this way." 52 The strikers employed the visiting system to achieve political goals, and Magnes softened the blow for the British authorities by implying that they would also gain politically from the pacifying effect of visiting. Since Magnes already served as a prison visitor, the inference might allude to the administration's objection to the panel's continuation. Perhaps the term "employed" hinted at a plan to hire salaried visitors or regular visitors to all of Palestine's prisons. ${ }^{53}$ The requirement that such visitors should be "trustworthy" alluded to British interests.

Despite the British promise that the high commissioner would seriously consider the terms of the settlement negotiated by Magnes, the prisoners soon reported continued maltreatment. ${ }^{54}$ Political prisoners were placed in joint cells with criminal prisoners. Prisoners recovering from the hunger strike were beaten, shackled, and punished with a "bread and water" diet. ${ }^{55}$ In Acre Prison, newspapers and books, previously permitted for some of the political prisoners, were now forbidden for all; shaving and haircuts, smoking, and chess were not permitted; the food was of poor quality, and prisoners were not allowed to get food from outside; civilian clothes were not returned to prisoners who refused to wear the humiliating prison uniform, so they remained naked; bowing was reintroduced, and political prisoners were flogged. ${ }^{56}$ Ali and Yussef, on whose account the hunger strike had broken out, were returned to prison for only a few days before being transferred again to a labor camp. The Jewish prisoners asked: "Is it because they are Arab workers that they cannot sit in

52. Letter from Magnes to the Commandant, May 15, 1930.

53. In June 1929, the Prison Visitor's Committee addressed the establishment of a visitors' panel in Haifa. Minutes of the Second Meeting, June 18, 1929, 7. We do not know the exact date in 1930 from which the British put the Prison Visitors Committee on hold. If this occurred prior to the communist prisoners' hunger strike, Magnes may have been referring to the panel's reconstitution. If so, British ambivalence seems even more striking - asking the visitors' help on a political matter shortly after terminating the practice for overstepping the role of social work. However, in the prisoners' letter, they refer to the committee as an existing one. Without knowing definitively the date of the panel's termination, we cannot reach decisive conclusions.

54. Letter from the Police and Prisons Commander to Dr. Magnes, May 16, 1930, P3-2307, CAHJP.

55. Letter from R. to Dr. Magnes, May 19, 1930, P3-2307, CAHJP.

56. Letter from nineteen political prisoners in Acre Prison to the Government Commission on Prisons, to Dr. Magnes, May 22, 1930, P3-2307, CAHJP; letter from Yechiel Zilberstein to Dr. Magnes, May 21, 1930, P3-2307, CAHJP; letter from the political prisoner Noah to Dr. Magnes, June 24, 1930, P3-2307, CAHJP. 
the same cell with the Jewish political prisoners?"57 The political prisoners demanded better treatment than that accorded to criminal prisoners and vehemently protested against discrimination between Jews and Arabs:

We cannot silently ignore the reprehensible maltreatment of political prisoners. As people of culture and consciousness we cannot live like savages, without a book, a newspaper etc. We cannot stand the degrading hunger. Most of all, we protest against racial and national discrimination. ${ }^{58}$

The prisoners reminded the British officials that they had ended the strike because they relied on Dr. Magnes's promise that the government would revise the law concerning political prisoners. Instead, they found themselves worse off than before, and they announced another hunger strike, first in Acre Prison. ${ }^{59}$ The prisoners asserted that the strike would end as soon as the commandant of the police promised that Arab political prisoners in Acre Prison, like their Jewish counterparts, would not need to bow. ${ }^{60}$ We have no documentation about the authorities' response, but the lack of further newspaper reports implies that the hunger strike was soon over. Later in 1930, regulations issued under the Prison Ordinance extended special treatment "to convicted prisoners who by their social status, education and habits of life are accustomed to a superior mode of living, and to any other prisoner to whom the Court in passing sentences directs that the special treatment shall apply." ${ }^{\prime 1}$ Magnes continued to deal with complaints about the infringement of the revised prison regulations.

This episode demonstrates various ways in which the colonized used the visiting system to exert agency. The communist prisoners used it as a channel for political negotiation, a move that resulted in political victory and the change of prison regulations. The prisoners also used the visiting system to exert agency within the internal politics of the colonized population. They expressed explicit suspicion against the cooperation of the visitors with the authorities. This implies a distinction between the colonized, who were collaborators, and those individuals who were resilient to the colonial rule. Magnes clearly exerted agency. His mediation advanced egalitarian values that were compatible with his worldview. His intervention was deemed necessary by both the prisoners and the British.

Although the British were disinclined to extend the visitors' mandate beyond pure welfare work, they were willing to use Magnes's intervention to negotiate a way out of a political crisis and empowered him to make commitments of a clearly political nature on behalf of the British government. The dignified position of the visitors in their community was a political resource in itself, and the visiting can be seen as a mechanism of co-optation, tailored to pacify local subjects and to perpetuate the colonial difference, as reflected in the composition of the first panel of visitors- two Arabs, two Jews, and one American. The combination reflects a careful attempt to create a balance between

57. Letter from nineteen political prisoners, May 22, 1930.

58. Letter from nineteen political prisoners, May 22, 1930.

59. Letter from political prisoners to Dr. Magnes, May 26, 1930, P3-2307, CAHJP.

60. Letter from Hans Kohn, a member of the Prison Visitors Committee to Dr. Magnes, May 20, 1930, P3-2307, CAHJP.

61. Memorandum written by H. F. Downie, September 27, 1935, CO-733-284-18, TNA. 
Jews and Arabs. The fact that all five visitors were well known and respected within their communities may indicate an effort to recruit local leadership into meaningful cooperation. The political prisoners who participated in the 1930 hunger strike explicitly opined that the institution of prison visits was only a humanistic façade veiling oppressive practices.

The visitors represented the prisoners of their local community. This case is especially interesting because the Jewish prisoners involved Magnes, a Jewish prison visitor, in their protest against the transfer of two Arab prisoners, Ali and Yussef, to labor camps. By advocating for the welfare of the political prisoners, Magnes not only acted to supervise and improve the prison administration but also advanced the prisoners' universalist agenda of solidarity and equity between Arabs and Jews. The political nature of Magnes's actions as a prison visitor is also apparent in his personal connections with the British leadership. Magnes communicated directly with the top-ranked authority, the commandant of the police, Arthur Stephen Mavrogordato, who delivered his messages directly to the high commissioner and Attorney General Bentwich. Magnes's status and position made him welcome in British circles, and he fulfilled his role in a manner loyal to the Mandate authorities. He visited the striking prisoners only after receiving official authorization (although he informally brought the matter to Bentwich's attention beforehand), and he explained the formal British policy to the prisoners.

The role of prison visitor bolstered Magnes's position as a leader within the Jewish community. The letters political prisoners sent to him—blunt and commanding at first-became gradually more respectful. However, they also conveyed suspicion that the visits camouflaged unjust colonial practices and served to co-opt resistance. This episode exemplifies how the colonized subjects were able to use prison visitation to exert agency over their situation. Like the British, they used it as a political tool, imbuing this practice with various, even contradictory, meanings.

\section{Prison Visiting as a National Tool}

Despite the discontinuation of the prison visiting committee early in 1930, the initial arrangements that it designed took root in the years to come. During the 1930s, local communities acted to improve conditions of imprisonment and promoted the welfare of prisoners from their communities, often assisted by visits of attorneys or men of religion. For example, representatives of the Haifa Committee of the Jewish Community visited Acre Prison to lobby for a kosher kitchen and the improvement of the food. ${ }^{62}$ The director of the Legal Aid Committee of the Haifa Committee of the Jewish Community was allowed to visit prisoners and assisted them on behalf of the community. ${ }^{63}$

62. Letter to the chairman of the Haifa Hebrew community, November 16, 1937, 4873 201-6, Haifa Municipality Archives (HMA).

63. Letter from the Legal Aid Department of the Haifa Committee of the Jewish Community to Pavel Weizler, June 3, 1934, 5381 269-11, HMA. 
Representatives of local communities wrote letters of complaint pertaining to maltreatment, ${ }^{64}$ arrangements to provide legal representation, holiday meals and kosher food, and care for released prisoners and their families. ${ }^{65}$ There are also fundraising letters from the community members to finance the expenses, including assistance to released prisoners who were deported without proper clothing or economic means and help to those who were released in Palestine in job searches, transportation, accommodation, and basic support. ${ }^{66}$ Ensuring bail for illegal immigrants was also part of the communities' agenda. ${ }^{67}$ Community prisoner rights advocates were especially enthusiastic with respect to political prisoners. Supportive acts included delivering messages to and from members of insurgent organizations through rabbinical visits. The assistance was organized within the ethno-national community. Thus, the Jewish communities' committees assisted imprisoned illegal immigrants and political prisoners, and Arab aid organizations protested against the maltreatment of Arab prisoners during the Arab revolt. ${ }^{68}$

Up until 1940, however, aid to the prisoners was not officially structured as prison visiting. The bitter taste Palestine's administration felt as result of their subjects' successful political manoeuvring of the visiting system lingered as late as 1939, when Moody deflected the Colonial Office's suggestion to reestablish a prison visiting system in Palestine. Grattan Bushe, the Colonial Office's legal adviser, condoned the Howard League's initiative for this move and presented it to the reluctant Palestine administration. Moody answered that the time was "inopportune" for an endeavor that was complicated, which it was considering "the peculiar political, religious, racial and linguistic factors." 69

Although he was averse to visitors' involvement in matters of prison administration, Moody declared that the Mandate administration intended to revise the Prison Ordinance by adding a category of lay visiting justices whose duties "would not comprise sociological work such as is done by prison visitors" and whose appointment "will ensure that an outside body, unconnected with the administration of the prisons, makes regular visits."70 The hope of the British administration, as expressed in Mr. Moody's letter, was to create an objective, external mechanism through which to inspect and review the prisons. It therefore seems odd that the 1940 Prison Ordinance not only affixes the

64. See, for example, a series of complaints about prisoners' maltreatment submitted by various Arab groups in February 1937. These groups included the National Committees of Safed, Beersheba, and Jenin, representatives of the Beisan Tribes, the Moslem Youngmen's Society in Hebron, and the Women's Committee, Acre. "Correspondence and Model Prison Report."

65. Protocol no. 4, December 11, 1933, 5199 8-507 d, Tel Aviv Municipality Archives (TAMA).

66. Letter to the chairman, November 16, 1937; Tel Aviv City Council board meeting 176: decision to transfer 150 liras to assist prisoner families, December 22, 1937, 2 19-6-4, TAMA.

67. Letter from the Legal Aid Department, June 3, 1934; letter by Henrietta Szold, the head of the Jewish National Council Welfare Department, January 11, 1935, 5366 207-7, HMA.

68. Memorandum on Tel Aviv Community Committee Legal Department, March 1933- December 1933, 5199 507-8 c, TAMA.

69. Letter by Moody to Downie, January 11, 1939. In other colonies, the pressures of the metropolitan and colonial office sometimes took the form of the appointment of enquiry or advisory committees. The work of these committees echoed debates about the meaning of penal reform in the colonies, such as "civilizing" the Africans versus protecting them from harmful consequences of rapid Westernization, tensions between "civilization" and "violence" in colonial governance, tension between the goals of reform, and tensions between "punishment," "reform," and "productivity" (Bourgeat 2014; Hynd 2015). Bushe himself headed a committee that investigated the administration of justice in Kenya, Uganda, and Tanganyika in 1933 (Swanepoel 2017).

70. Letter by Moody to Downie, January 11, 1939. 
appointment of "fit and proper" community representatives as prison visitors in legislation but also grants them powers equivalent to those of the ex-officio justices. ${ }^{71}$

While the "law on the books" transmits the original reformist spirit of independent and muscular inspection, the British anxieties over criticism of Palestine's prison system by their local subjects were addressed outside official legislation. On behalf of the high commissioner, the chief secretary issued rules for the prison visitors. The rules declared that the visitors were "friends from outside-disinterested, unpaid and without missionary or political aims"; that they "do not constitute a committee" but, rather, form a panel of individuals; that "visitors are not concerned in any way with the administration or management of the prison"; and that their goal is to the raise the prisoners' thoughts from their prison surroundings and assist them on discharge. ${ }^{72}$ The new policy even led to the resignation of one of the old visitors, Dr. Schwabe, who criticized the concept of a panel of individuals with no right to suggest improvements to prison administration. This move demonstrated, Schwabe proclaimed, how the administration deliberately created the false impression of transparency and willingness to submit to public scrutiny, "where the public is blinded. To the outside world they say that the public inspects the operation of the government, but internally they limit public by making its participation worthless." 73 Schwabe wryly commented that the right term should now be "caregivers" rather than "visitors."

Nonetheless, the colonized were still able to exert agency through the visiting system. Community members sometimes collaborated with British authorities in the appointment of prison visitors. A newspaper report from 1941 announced the appointment of Rabbi Kalman Kupfer as a prison visitor in the Tel Aviv-Jaffa District. According to the report, Rabbi Kupfer had been appointed by the chief rabbinate with the approval of the Department of Police and Prisons, "with a view to ministering to the spiritual and religious needs of Jewish prisoners" (Palestine Post 1941, 3). ${ }^{74}$ Kupfer offered his services to Tel Aviv's Municipality Department of Social Services. He presented documentation of his success in the role of prison visitor in Vienna and a detailed memorandum of his vision of the prison visitor's role. ${ }^{75}$

Unlike the members of the first panel of prison visitors, Kupfer was hired on the basis of his professional experience and not on the basis of his ties with the authorities, and he was a salaried employee, not a volunteer, notwithstanding the new British rules. The Tel Aviv municipality agreed to contribute money for his monthly salary and asked other Jewish community councils to chip in so Kupfer could visit other prisons too. ${ }^{76}$ Kupfer represents a model of a professional prison visitor chosen and employed by the

71. Prison Ordinance no. 2, para. 21.

72. Notes for the Introduction and Guidance of Prison Visitors (attached to a letter), April 3, 1941, P3-2312, CAHJP.

73. Letter from Dr. Schwabe to Dr. Magnes, May 21, 1940, P3-2312, CAHJP (translated by the authors).

74. See also letter from the Superintendent of Police to Mayor Rokach, November 7, 1940, 04-1461, TAMA.

75. Letter from Tel Aviv Municipality Department of Social Services, September 20, 1940, 04-1461, TAMA; Rabbi Dr. Kalman Kupfer, "Work Agenda of the Social Service of Instructing Prisoners' Souls and Visiting in Tel Aviv's Mental Asylums for the Municipality's Social Work,” n.d., 04-1461, TAMA.

76. Letter from the Tel Aviv Municipality Social Services Department to the presidency of the General Council (Vaad Leumi) of the Jewish Community of Palestine, August 23, 1940, 04-1461, TAMA. 
community's official bodies. Individual volunteers who requested the municipality's support were turned down. ${ }^{77}$ This small example demonstrates both the community's agency and an attempt to curb it. It was the community who chose the visitor; the British merely executed the community's will. Nonetheless, the visitor's role was narrowly defined, with an emphasis on noncontroversial religious functions. ${ }^{78}$ In practice, Kupfer not only saw himself as a spiritual guide (he even signed his reports as "Rabbi Kalman Kupfer, a Guide of Souls") but also dedicated much time and attention to nonreligious social welfare.

Despite formal obstacles, lay participation in the inspection of the regime's prison system persisted once the British authorities introduced it. Civilians were granted remarkable access to prisons. Another outstanding feature of the arrangement was the creation of a panel that reflected the ethnic composition and religious denominations of the inmates. This system allowed regular visits to Jewish and Arab prisoners by representatives of their communities, who included lawyers, members of voluntary associations, religious figures, and political activists. The British authorities regarded the creation of a modern penitentiary system in Mandate Palestine as integral to the progress and enlightenment they purported to spread in the territory entrusted to their care. Thus, the local visiting system was part of the colonial civilizing mission. At the same time, the lay visiting system empowered the local subjects with agency. It enabled them to participate in the creation of humanitarian norms, to voice loud criticism of their rulers, and to advance national goals. Moreover, the tensions inherent in the visiting system made it vulnerable to political maneuvers and re-appropriation by the local population in Palestine.

\section{CONCLUSION}

The British transplanted into Palestine a well-established institution that enabled community representatives to visit prisoners and inspect prisons. The institution of prison visiting in Mandate Palestine involved a complex and sometimes conflicting array of practices, motives, interests, and relationships. Both the British rulers and their subjects made political use of this system, and both manifested ambivalence in their use of it. For the British, and particularly for dedicated reformers such as Nixon, prison visiting was as an important component of a progressive model of prison administration. Yet visiting was also integral to the civilizing mission. The British presented themselves as the transformers of the primitive and cruel system that was the legacy of their Ottoman predecessors, with prison administration as another mark of their superiority. ${ }^{79}$ Visiting was employed to maintain the "rule of colonial difference," as an administrative resource, and to pacify the colonized. The British prided themselves on adopting a

77. Letter from the Tel Aviv Municipality's Director of Social Services Department, September 8, 1942, 04-1461, TAMA.

78. Notwithstanding their narrow definition, rabbinical visits were also used for national purposes, such as exchanging messages between prisoners and the outside or smuggling classified information (Misgav 2007, 76, 131; Golan 2014, 64, 72).

79. Nixon describes how the British "quickly altered" the horrid conditions in the Ottoman prisons, despite institutional and budgetary constraints (Nixon 1935, 135). 
reformistic institution, but when they felt that the local visitors overstepped the "social" role designated for them, they reconsidered. Nonetheless, when they found themselves in a political crisis, such as presented to them by the 1930 hunger strike, they willingly entrusted political negotiations to the hands of a prison visitor.

As in their rulers' case, the manipulation of prison visitation on the part of the colonized manifested ambivalent and diverse ideologies, practices, and beliefs. In the 1930 hunger strike, protesters used the visiting mechanism to promote a universalist agenda of Arab and Jewish equality, but, on other occasions, it was used to advance separate national goals and support for prisoners of the same ethno-national group. The British ambivalence stemmed in part from the inherent tension between the goals of reform and keeping the colonial order and in part from a political process through which British officials, local elites, and other members of colonized communities imbued the practice of prison visits with a range of meanings that influenced the dynamics between the various players. The repurposing of the reformist ideology as part of the project of the civilizing mission was vulnerable to the claims of the colonized, as the events of the 1930 hunger strike revealed.

In this historic episode, the colonized employed the mechanism of prison visiting to advance claims for ethnic and national equality, striking at the very core principle of colonial difference. Responding to the meaning that Palestine's lay visitors instilled in the visiting system, the British tried to recreate a colonial scheme in which colonial order remained and the colonized did not overstep their role and intervene in prison administration. Reform was to be hailed yet contained.

\section{REFERENCES}

Agozino, Biko. 2004. "Imperialism, Crime and Criminology: Towards the Decolonisation of Criminology." Crime, Law and Social Change 41, no. 4: 343-58.

Anderson, Clare. 2007. The Indian Uprising of 1857-8: Prisons, Prisoners and Rebellion. London: Anthem Press.

- 2008. "The Politics of Punishment in Colonial Mauritius, 1766-1887." Cultural and Social History 5, no. 4: 411-22.

Anderson, David. 2005. Histories of the Hanged: The Dirty War in Kenya and the End of Empire. New York: WW Norton \& Company.

Arnold, David. 1994. "The Colonial Prison: Power, Knowledge and Penology in Nineteenth-Century India." In Subaltern Studies VIII: Essays in Honour of Ranajt Guha, edited by D. Arnold and D. Hardiman, 148-87. New Delhi: Oxford University Press.

Barak-Gorodetsky, David. 2018. Jeremiah in Zion: The Religion and Politics of Judah Leib Magnes. Beer Sheba: Ben Gurion University Press.

Bentwich, Norman. 1938. "The New Criminal Code for Palestine." Journal of Comparative Legislation and International Law 20, no. 1: 71-79.

. 1954. For Zion's Sake: A Biography of Judah L. Magnes, First Chancellor and First President of the Hebrew University of Jerusalem. Philadelphia, PA: Jewish Publication Society of America.

Bernault, Florence. 2003. "The Politics of Enclosure in Colonial and Post-Colonial Africa." In A History of Prison and Confinement in Africa, edited by F. Bernault, 1-53. Portsmouth, UK: Heinemann.

Berridge, W. J. 2012. "Ambivalent Ideologies and the Limitations of the Colonial Prison in Sudan, 1898-1956." Journal of Eastern African Studies 6, no. 3: 444-62.

Bourgeat, Emilie. 2014. "Penality, Violence and Colonial Rule in Kenya (c. 1930-1952)." PhD diss., University of Oxford. 
Brown, Ian. 2007. "A Commissioner Calls: Alexander Paterson and Colonial Burma's Prisons.” Journal of Southeast Asian Studies 38, no. 2: 293-308.

Chatterjee, Partha. 2020. The Nation and Its Fragments: Colonial and Postcolonial Histories. Princeton, NJ: Princeton University Press.

Cooper, Robert Alan. 1976. "Ideas and Their Execution: English Prison Reform." Eighteenth Century Studies 10, no. 1: 73-93.

— 1981. "Jeremy Bentham, Elizabeth Fry, and English Prison Reform." Joumal of the History of Ideas 42, no. 4: 675-90.

Davar. 1930. "Another Hunger Strike." May 29.

Devarmani, N. G., and R. N Mangoli. 2015. "Prison Visiting System in India." Global Journal of Research in Social Sciences 1, no. 1: 19-21.

Fisher, George. 1995. "The Birth of the Prison Retold." Yale Law Journal 104, no. 6: 1235-1324.

Foucault, Michel. 1977. Discipline and Punish: The Birth of the Prison. New York: Pantheon Books.

Fourchard, Laurent. 2003. "Between Conservatism and Transgression: Everyday Life in the Prisons of Upper Volta, 1920-1960.” In A History of Prison and Confinement in Africa, edited by F. Bernault, 135-53. Portsmouth, UK: Heinemann.

Gibson, Mary. 2011. "Global Perspectives on the Birth of the Prison." American Historical Review 116, no. 4: 1040-63. http://doi.org/10.1086/ahr.116.4.1040.

Golan, Zev. 2014. The History of the Jerusalem Central Prison during the British Mandate. Jerusalem: Yair Press.

Greene, Roberta R., Shira Hantman, Yair Seltenreich, Mustafa Abbasi, and Nancy Greene. 2017. Living in Mandatory Palestine: Personal Narratives of Resilience of the Galilee during the Mandate Period 1918-1948. New York: Routledge.

Guha, Ranajit. 1997. A Subaltern Studies Reader, 1986-1995. Minneapolis: University of Minnesota Press.

Howard, John. 1777. The State of the Prisons in England and Wales: With Preliminary Observations, and an Account of Some Foreign Prisons. London: William Eyres.

Hughes, Matthew. 2009. "The Banality of Brutality: British Armed Forces and the Repression of the Arab Revolt in Palestine, 1936-39." English Historical Review 124, no. 507: 313-54. 2013. "A British 'Foreign Legion'? The British Police in Mandate Palestine." Middle Eastern Studies 49, no. 5: 696-711.

. 2019. "Women, Violence, and the Arab Revolt in Palestine, 1936-39." Journal of Military History 83, no. 1: 523-56.

Hynd, Stacey. 2011. "Law, Violence and Penal Reform: State Responses to Crime and Disorder in Colonial Malawi, c.1900-1959." Journal of Southern African Studies 37, no. 3: 431-47.

. 2015. "Insufficiently Cruel' or 'Simply Inefficient'?: Discipline, Punishment and Reform in the Gold Coast Prison System, c. 1850-1957." In Transnational Penal Cultures: New Perspectives on Discipline, Punishment and Desistance, edited by Vivien Miller and James Campbell, 19-35. London: Routledge.

Ibhawoh, Bonny. 2008. Imperialism and Human Rights: Colonial Discourses of Rights and Liberties in African History. Albany: State University of New York Press.

Ignatieff, Michael. 1978. A Just Measure of Pain: The Penitentiary in the Industrial Revolution, 1750-1850. London: Macmillan.

Kalbian, Vicken V. 2018. "The Constant Consul of Jerusalem: Edward W. Blatchford." Jerusalem Quarterly 76: 46-59.

Kaspi, Joshua. 1984. "Prisons in Mandate Palestine." Kathedra [Hebrew] 32: 141-74.

Knox-Mawer, Ronald. 1958. "The Jury System in British Colonial Africa." Journal of African Law 2, no. 3: 160-63.

Kolinsky, Martin. 1993. Law, Order, and Riots in Mandatory Palestine, 1928-35. London: St. Martin's Press.

Kolsky, Elizabeth. 2005a. "Codification and the Rule of Colonial Difference: Criminal Procedure in British India." Law E History Review 23, no. 3: 631-83.

. 2005b. "A Note on the Study of Indian Legal History." Law E⿱ History Review 23, no. 3: 703-6. 2010. Colonial Justice in British India. Cambridge, UK: Cambridge University Press. 
Lalli, Upneet. 2000. "Attitude to Prison Reforms: An Empirical Survey." Indian Journal of Criminology 1, no. 1: 32-45.

Likhovski, Assaf. 2006. Law and Identity in Mandate Palestine. Edited by Thomas A. Green and Hendrik Hartog. Chapel Hill: University of North Carolina Press.

Lockman, Zachary. 1996. Comrades and Enemies: Arab and Jewish Workers in Palestine, 1906-1948, Comrades and Enemies. Berkeley: University of California Press.

Louis, William Roger. 2006. Ends of British Imperialism: The Scramble for Empire, Suez and Decolonization: Collected Essays. London: I. B. Tauris.

Luddy, Maria. 1988. "Women and Charitable Organisations in Nineteenth Century Ireland." Women's Studies International Forum 11, no. 4: 301-5. https://doi.org/10.1016/0277-5395(88) 90068-4.

McClendon, Thomas. 2018. "Whipping Boys: South Africa's Limited Reform of Judicial Corporal Punishment in the 1960s and 1970s." African Studies 77, no. 3: 354-77.

McGowen, Randall. 1995. "The Well-Ordered Prison: England, 1780-1865." In Morris and Rothman, Oxford History of the Prison, 79-109.

Miller, Ylana N. 1985. Government and Society in Rural Palestine, 1920-1948. Austin: University of Texas Press.

Misgav, Tal. 2007. The Story of Latrun Internment Camp in the Mandate Period. Jerusalem: Ariav.

Moore, J. M. 2014. "Is the Empire Coming Home? Liberalism, Exclusion and the Punitiveness of the British State." In Papers from the British Criminology Conference, edited by A. Millie, 31-48. Liverpool, UK: British Society of Criminology, University of Liverpool.

Nixon, Margaret. 1935. "Palestine: Women and Girl Offenders." Howard Journal 4, no. 2: 135-38. Palestine Bulletin. 1928. "Palestine from Day to Day." June 10.

— 1930. "Palestine in Parliament." May 21.

Palestine Post. 1934. "Social and Personal." August 21.

— 1935. "Social and Personal." February 3.

— 1941. "Prison Visitor in Tel-Aviv-Jaffa District." February 5.

Paterson, Alexander. 1940. "The Prison Visitor in England." Prison Journal 20, no. 2-3: 51-54.

Paton, Diana. 2004. No Bond but the Law: Punishment, Race, and Gender in Jamaican State Formation, 1780-1870. Durham, NC: Duke University Press.

Prasad, Anshuman. 2012. "Working against the Grain: Beyond Eurocentrism in Organization Studies." In Against the Grain: Advances in Postcolonial Organization Studies, edited by Anshuman Prasad, 13-31. Copenhagen: Copenhagen Business School Press.

Rothman, David J. 1971. The Discovery of the Asylum: Social Order and Disorder in the New Republic. Boston, MA: Little, Brown.

Rozin, Orit. 2016. A Home for all Jews: Citizenship, Rights, and National Identity in the New Israeli State. Waltham, MA: Brandeis University Press.

Schwan, Anne. 2010. "Dreadful beyond Description." European Journal of English Studies 14, no. 2: $107-20$.

Scicluna, Sandra, and Paul Knepper. 2008. "Prisoners of the Sun: The British Empire and Imprisonment in Malta in the Early Nineteenth Century." British Journal of Criminology 48, no. 4: 502-21.

Sherman, Taylor C. 2009. "Tensions of Colonial Punishment: Perspectives on Recent Developments in the Study of Coercive Networks in Asia, Africa and the Caribbean." History Compass 7, no. 3: 659-77.

Smith, Charles D. 2017. Palestine and the Arab-Israeli Conflict: A History with Documents. 9th ed. Boston, MA: Bedford/St. Martin's.

Spierenburg, Pieter. 1998. "The Body and the State: Early Modern Europe." In Morris and Rothman, Oxford History of the Prison, 44-70.

Stephen, Peté. 2008. "A Brief History of Human Rights in the Prisons of Africa." In Human Rights in African Prisons, edited by J. Sarkin, 40-66. Athens: Ohio University Press.

Stockdale, Eric. 1983. "A Short History of Prison Inspection in England." British Journal of Criminology 23, no. 3: 209-88. 
Stoler, Ann Laura. 2009. Along the Archival Grain: Epistemic Anxieties and Colonial Common Sense. Princeton, NJ: Princeton University Press.

Strawson, John. 2010. Partitioning Palestine: Legal Fundamentalism in the Palestinian-Israeli Conflict. London: Pluto Press.

Swanepoel, Paul. 2017. "Colonial Judges, Administrative Officers and the Bushe Commission in Interwar Kenya and Tanganyika." Fundamina 23, no. 1: 89-110.

Tal-Krispin, Hila. 2010. Renaissance at Sodom: The Contribution of Palestine Potash Ltd to the Development of Dead-Sea Region and Palestine, 1930-1948. Beer Sheba: Ben Gurion Research Institute.

Wilson, Chris. 2019. "Incarcerating the Insane: Debating Responsibility for Criminal Lunatics between Prisons, Hospitals, and Families in British Mandate Palestine." Contemporary Levant 4, no. 1: 39-51.

Zalashik, Rakefet, and Nadav Davidovitch. 2011. "Gender and Mental Health in the Yishuv during the First Decade of the State of Israel." In Gender in Israel: New Studies on Gender in the Yishuv and State, edited by M. Shilo and G. Katz, 306-35. Beer Sheba: Ben Gurion Research Institute.

Zinoman, Peter. 2001. The Colonial Bastille: A History of Imprisonment in Vietnam, 1862-1940. Berkeley: University of California Press. 